\title{
Low dose of arsenic trioxide inhibits multidrug resistant-related P-glycoprotein expression in human neuroblastoma cell line
}

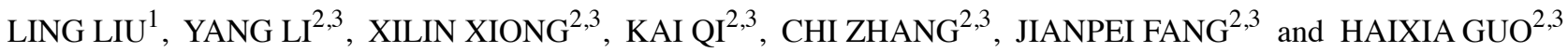 \\ ${ }^{1}$ Department of Pediatric, Affiliated Hospital of Guangdong Medical University, Zhan Jiang, \\ Guangdong 524000; ${ }^{2}$ Guangdong Provincial Key Laboratory of Malignant Tumor Epigenetics and \\ Gene Regulation and ${ }^{3}$ Department of Pediatric Hematology/Oncology, Sun Yat-Sen Memorial Hospital, \\ Sun Yat-Sen University, Guangzhou, Guangdong 510120, P.R. China
}

Received May 26, 2016; Accepted August 22, 2016

DOI: $10.3892 /$ ijo.2016.3756

\begin{abstract}
This study investigated arsenic trioxide $\left(\mathrm{As}_{2} \mathrm{O}_{3}\right)$, cisplatin (DDP) and etoposide (Vp16) on the anticancer effects and P-glycoprotein (P-gp) expression in neuroblastoma (NB) SK-N-SH cells. The potential influence of $\mathrm{As}_{2} \mathrm{O}_{3}$, DDP and Vp16 currently included in NB routine treatment protocols on cytotoxicity in SK-N-SH cells was measured by flow cytometry and drug half-maximal inhibitory concentration $\left(\mathrm{IC}_{50}\right)$ was established. Moreover, chemotherapeutic agent-mediated changes of cellular expression levels of resistant-related P-gp, was monitored using western blotting. The data showed that $\mathrm{As}_{2} \mathrm{O}_{3}$, DDP and Vp16 significantly inhibited the growth and survival of the SK-N-SH cells at different concentration. Notably, the levels of apoptosis were upregulated in SK-N-SH cells with an acceleration of the exposure time and the concentration of $\mathrm{As}_{2} \mathrm{O}_{3}$, DDP and Vp16. $\mathrm{As}_{2} \mathrm{O}_{3}$, DDP and Vp16 were observed with their $\mathrm{IC}_{50}$ values on SK-N-SH cells being $3 \mu \mathrm{M}, 8$ and $100 \mu \mathrm{g} / \mathrm{ml}$, respectively. Flow cytometry analysis showed that $\mathrm{As}_{2} \mathrm{O}_{3}$ at low concentrations in SK-N-SH cells led to enhanced accumulation of cell populations in $\mathrm{G} 2 / \mathrm{M}$ phase with increasing the exposure time, and increased levels of apoptosis. In contrast, we observed that SK-N-SH cell populations arrested in S phase by DDP and Vp16. In vitro examination revealed that following pretreatment of SK-N-SH cells with $\mathrm{As}_{2} \mathrm{O}_{3}$, the expression of $\mathrm{P}$-gp was not increased. The expression of P-gp downregulation were noted following the group treated by $\mathrm{As}_{2} \mathrm{O}_{3}$ at 2 and $3 \mu \mathrm{M}$. Exposed to $\mathrm{As}_{2} \mathrm{O}_{3}$ at $3 \mu \mathrm{M}$ for $72 \mathrm{~h}, \mathrm{SK}-\mathrm{N}-\mathrm{SH}$ cells exhibited lower expression of P-gp than $2 \mu \mathrm{M} \mathrm{As}_{2} \mathrm{O}_{3}$ for $72 \mathrm{~h}$. In contrast, the expression of P-gp was upregulated by DDP and VP16. In summary, SK-N-SH cells were responsive to chemotherapeutic
\end{abstract}

Correspondence to: Dr Yang Li, Guangdong Provincial Key Laboratory of Malignant Tumor Epigenetics and Gene Regulation, Sun Yat-Sen Memorial Hospital, Sun Yat-Sen University, Guangzhou, Guangdong 510120, P.R. China

E-mail: drliyang@126.com

Key words: neuroblastoma, arsenic trioxide, P-glycoprotein, multidrug resistance agent-induced apoptosis in a dose-dependent and time-dependent manner. In particular, ours findings showed that low dose of $\mathrm{As}_{2} \mathrm{O}_{3}$ markedly reduced the P-gp expression and increased apoptotic cell death in human NB cell line.

\section{Introduction}

Neuroblastoma (NB) is the most commonly occurring extracranial solid neoplasm diagnosed in young children that shows aggressive behaviour. NB is a childhood malignancy, which may originate from multipotent crest cells of the sympathetic nervous system and accounts for 8 to $10 \%$ of all childhood cancers, yet disproportionately responsible for $15 \%$ of all childhood cancer deaths $(1,2)$. Approximately $40 \%$ of the children with NB have an aggressive form with a 5-year event-free survival rate $<50 \%$ (3). Despite intensive treatment protocols including myeloablative cytotoxic therapy and 13-cis-retinoic acid (4) or anti-GD2 immunotherapy (5) that were applied, the majority of the children diagnosed with high-risk NB experience a recurrence and the long-term survival $<40 \%(6,7)$. Although the initial tumor response is very good in children with high-risk NB, $>60 \%$ of the treated patients experience relapse and still die of this disease $(8,9)$. Currently, in the clinic relapsed/refractory patients still lack effective treatment strategies which has been recognized as a critical problem, and the poor outcome remains.

Initially, responsiveness to chemotherapy in NB tumors is high (10), but eventually, these patients often relapse and develop a multiple drug resistant (MDR) phenotype. Acquired MDR is a major contributing factor to chemotherapeutic treatment failure $(11,12)$. MDR is a phenomenon in which tumor cells become resistant to diverse chemical structures and functionally unrelated chemotherapeutic agents (13). Once NB develops MDR, as a consequence, the long-term survival rate of NB patients is poor (11). Strategies to improve the outcomes in high-risk NB include 13-cis-retinoic acid, anti-GD2 immunotherapy and bone marrow transplantation. Still, the high-risk NB patients eventually develop progressive disease.

The mechanism of NB developing MDR is complicated and several factors are involved, including loss of function of p53 (14), overexpression of the membrane bound ATP-binding 
cassette transporters (ABC proteins) (13), inactivation of the detoxification system, changing drug targets and significant downregulation of apoptotic cell death-related genes (12). Especially, the most often observed the main mechanism for MDR includes loss of function of p53, high levels of P-glycoprotein (P-gp) and MRP1 (multidrug resistance-related protein). When overexpressed in neoplastic tissue, $\mathrm{P}-\mathrm{gp}$ and MRP1 effectively extrude various cytotoxic agents and eliminate chemotherapeutics, may contribute to their refractoriness to large group of cytotoxic drugs, such as anthracycline, epipodophyllotoxin, vinca alkaloids, taxanes and methotrexate $(15,16)$.

A number of conventional anticancer agents show cytotoxic effects by interfering with DNA or RNA replication and protein synthesis in cancer cells, as well as activation of the expression of p53 gene, but unfortunately, most of chemotherapy drugs can also increase gene mutations and change tumor suppressor gene expression. In some highly malignant tumor cells, apoptotic mechanisms of secondary damage due to chemotherapy, such as inactivation of p53 gene containing cysteine aspartic protease (caspase) fail, limiting their application. These include increased DNA repair, altered target sensitivity, decreased apoptotic response, and numerous aberrant signal transduction pathways. Commonly used chemotherapy drugs such as Dox and DDP induce tumor cells formed MDR in that they can increase the leukemia cells or NB the expression of P-gp. While increasing the dose of chemotherapeutic agents may successfully eliminate MDR to some extent, but high-dose chemotherapy can cause inevitable severe side-effects, such as heart, liver, kidney and hearing damage, thus patients can not tolerate and abandon treatment (17). This prompted us to investigate new treatment strategies against MDR NB caused by diverse mechanisms.

It is necessary to develop potential chemotherapeutic strategies to enhance chemosensitivity and to overcome the MDR. While in the last few years, arsenic was also seen as a carcinogen, but recent reports have indicated that arsenic trioxide $\left(\mathrm{As}_{2} \mathrm{O}_{3}\right)$ has been found to inhibit cell growth and/ or induce apoptosis in acute promyelocytic leukemia (APL) $(18,19)$ and successfully employed as a highly effective agent for other malignancies. $\mathrm{As}_{2} \mathrm{O}_{3}$ has been associated with complicated anticancer mechanisms, including induction of tumor cell differentiation, inhibition of tumor cell growth and induce apoptosis (20), although the efficacy of $\mathrm{As}_{2} \mathrm{O}_{3}$ on different tumors remains unsure (21). In the APL cells, $\mathrm{As}_{2} \mathrm{O}_{3}$ exert antitumor effect by acting on the PML/RARA as target (22); in other tumor cells, the antitumor effect was associated with activation of caspase cascade leading to apoptotic cell death and reduced expression of Bcl-2 gene (23).

Many studies have confirmed that $\mathrm{As}_{2} \mathrm{O}_{3}$ has the capacity to kill NB cells in vitro and in vitro (24-27). Despite that invasive tumor in the body often is in a low oxygen environment, Karlsson et al (26) show that the cytotoxic effect of $\mathrm{As}_{2} \mathrm{O}_{3}$ is retained under hypoxic conditions, even in MDR NB cells. In contrast, the cell death induced by the conventionally used drug etoposide (Vp16) was significantly impaired in Vp16-sensitive NB cell lines cultivated at hypoxia. These results support the idea of using $\mathrm{As}_{2} \mathrm{O}_{3}$ as an efficient treatment strategy also in solid tumors with hypoxic areas like NB. Memorial SloanKettering Cancer Center has completed phase II clinical trials of treatment of NB and other malignancies, preliminarily showing that $\mathrm{As}_{2} \mathrm{O}_{3}$ treatment of MDR NB has better safety, the primary efficacy outcome are not yet available.

Some investigators have shown that $\mathrm{As}_{2} \mathrm{O}_{3}$-induced NB apoptosis is caused by downregulation of $\mathrm{Bcl}-2$ protein, activate caspase, the generation of reactive oxygen species, loss of the mitochondrial transmembrane potential, and cell cycle arrest in $\mathrm{G} 1$ or $\mathrm{G} 2 / \mathrm{M}$ phase (23). Little is known about $\mathrm{As}_{2} \mathrm{O}_{3}$ impact on the expression of multidrug resistant-related P-gp in NB, however, further studies are required. We examined the effect of $\mathrm{As}_{2} \mathrm{O}_{3}$ and conventionally used drugs on P-glycoprotein by western blotting; flow cytometric assay was used to examine the impact of various antitumor drugs on cell cycle and cell apoptosis in SK-N-SH cells.

Overall, we compared and contrasted the effects of $\mathrm{As}_{2} \mathrm{O}_{3}$ and conventional chemotherapeutic drugs at varying concentrations on the expression of P-gp and the impact of cell cycle in NB SK-N-SH cells. In this study, our results indicated that compared to conventional chemotherapeutic drugs, $\mathrm{As}_{2} \mathrm{O}_{3}$ mediates this effect by inducing apoptosis and provides a suggestion that $\mathrm{As}_{2} \mathrm{O}_{3}$ is a potential chemotherapeutic reagent for the treatment of NB including MDR NB.

\section{Materials and methods}

Cell line. Human NB cell line, SK-N-SH, was purchased from Cell Bank of Sun-Yet Sen Medical School. SK-N-SH cells were grown in DMEM supplemented with $12 \%$ fetal calf serum (FCS), $100 \mathrm{U} / \mathrm{ml}$ penicillin and $100 \mu \mathrm{g} / \mathrm{ml}$ streptomycin. Cells were maintained at $37^{\circ} \mathrm{C}$ in a humidified incubator of $5 \% \mathrm{CO}_{2} / 95 \%$.

Reagents. $\mathrm{As}_{2} \mathrm{O}_{3}, \mathrm{VP} 16$ and DDP was purchased from Sun Yat-Sen Memorial Hospital. $\mathrm{As}_{2} \mathrm{O}_{3}$ was dissolved in phosphate-buffered saline as $10 \mathrm{mM}$ stock and kept at $4^{\circ} \mathrm{C}$. MDR1/ABCB1 (D3H1Q) rabbit $\mathrm{mAb}$ and anti-GAPDH antibody rabbit antibody was obtained from Cell Signaling Technology. HRP affinipure goat anti-rabbit $\mathrm{IgG}$ for western blotting was purchased from Sigma Chemical Co. Immobilon western chemiluminescent HRP substrate was purchased from Millipore, and DMEM medium and trypsin were purchased from Hyclone. PVDF membrane was purchased from Millipore, and FBS was purchased from NBQQ.

Flow cytometry with Annexin V-PI staining for apoptosis. Logarithmically growing cells were exposed to various concentrations and exposure intervals of $\mathrm{As}_{2} \mathrm{O}_{3}, \mathrm{VP} 16$ and DDP. For the experiments, cells were seeded in 6-well plates at a density of $\sim 3 \times 10^{5}$ cells per milliliter at $37^{\circ} \mathrm{C}$ in a humidified incubator of $5 \%$ for $24 \mathrm{~h}$. For determination of cell growth inhibition, cells were exposed to varying concentrations of $\mathrm{As}_{2} \mathrm{O}_{3}, \mathrm{VP} 16$ and DDP at $37^{\circ} \mathrm{C}$ for the indicated time. After treatment, the cells at $1-5 \times 10^{5} / \mathrm{ml}$ harvested from culture and washed by PBS, and then resuspended in $200 \mu \mathrm{l}$ staining solution that contained $5 \mu \mathrm{l}$ of Annexin V-FITC and $10 \mu \mathrm{l}$ propidium iodide, according to the protocol of the Annexin V Staining kit. The proportion of cell apoptosis was analyzed by flow cytometry within one hour. The $\mathrm{IC}_{50}$ value resulting from $50 \%$ inhibition of cell growth was calculated graphically as a comparison with the control. All treatments were done in triplicates and the experiments were repeated three times. 
A

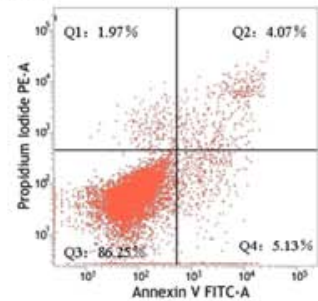

0

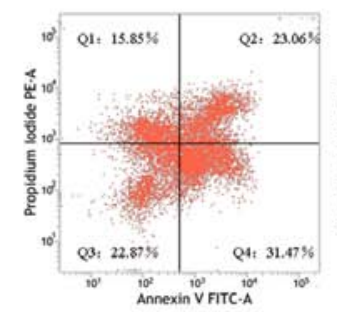

$3 \mu \mathrm{M} \mathrm{As}_{2} \mathrm{O}_{3}$

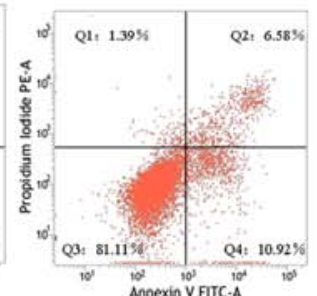

$1 \mu \mathrm{M} \mathrm{As}_{2} \mathrm{O}_{3}$

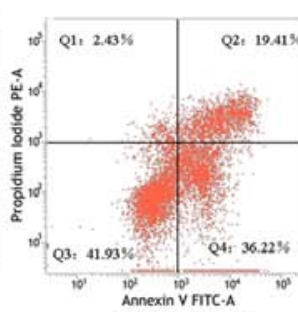

$4 \mu \mathrm{M} \mathrm{As}_{2} \mathrm{O}_{3}$

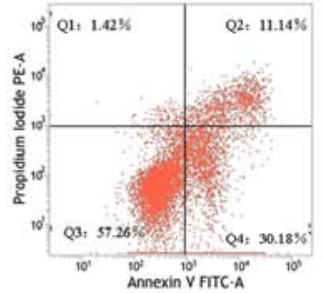

$2 \mu \mathrm{M} \mathrm{As}_{2} \mathrm{O}_{3}$

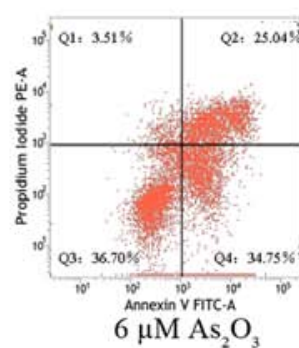

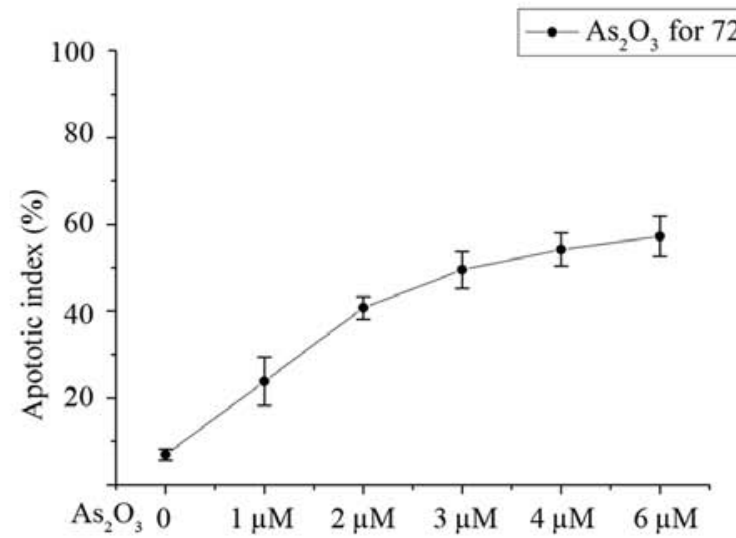

B
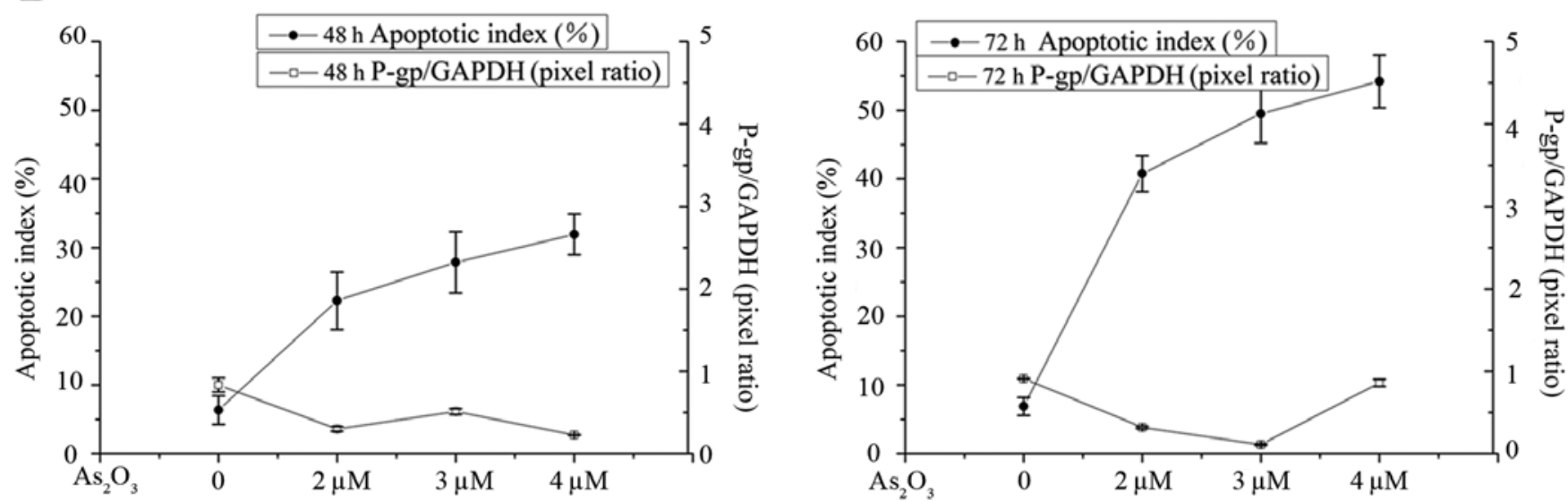

Figure 1. Different cytotoxic agents affect specific apoptosis of SK-N-SH cells and expression levels of P-gp. (A) Cytotoxicity of As $\mathrm{O}_{3}$ after various time induction at given concentrations in SK-N-SH cells. After 72-h exposure to various concentrations of $\mathrm{As}_{2} \mathrm{O}_{3}$, cell viability was assayed by flow cytometry. Dose-response curves of SK-N-SH cells upon $\mathrm{As}_{2} \mathrm{O}_{3}$ treatment. The $\mathrm{As}_{2} \mathrm{O}_{3} \mathrm{IC}_{50}$ of SK-N-SH cells was $3 \mu \mathrm{M}$. (B) Cells with decreased expression levels of P-gp show increased sensitivity to $\mathrm{As}_{2} \mathrm{O}_{3}$ induced apoptosis. Cells were exposed to the indicated concentrations of $\mathrm{As}_{2} \mathrm{O}_{3}$ for 48 and $72 \mathrm{~h}$ and exhibit decreased expression levels of P-gp. All data are presented as the mean $( \pm$ SEM) from at least 3 independent experiments.

Flow cytometry for cell cycle. Logarithmically growing cells were exposed to various concentrations and exposure intervals of $\mathrm{As}_{2} \mathrm{O}_{3}, \mathrm{VP} 16$ and DDP. For the experiments, cells were seeded in 6-well plates at a density of approximately $3 \times 10^{5}$ cells per milliliter at $37^{\circ} \mathrm{C}$ in a humidified incubator of $5 \%$ for $24 \mathrm{~h}$. $\mathrm{IC}_{50}$ of $\mathrm{As}_{2} \mathrm{O}_{3}$ was added to the experimental group. According to the literature (28) and our result of $\mathrm{IC}_{50}$ of $\mathrm{As}_{2} \mathrm{O}_{3}$ on SK-N-SH cells, we used $3 \mu \mathrm{M} \mathrm{As}_{2} \mathrm{O}_{3}$-treated SK-N-SH cells for 48 and $72 \mathrm{~h} . \mathrm{IC}_{50}$ of DDP and Vp16 were added to the drug control groups. According to our prior research, we chose $8 \mu \mathrm{g} / \mathrm{ml}$ DDP-treated cells for 12 and $24 \mathrm{~h}, 100 \mu \mathrm{g} / \mathrm{ml} \mathrm{Vp16-treated} \mathrm{cells}$ for 24 and $48 \mathrm{~h}$. Each group was set in three parallel wells. Untreated or drug-treated cells were centrifuged, washed with PBS and fixed with ice-cold $75 \%$ ethanol overnight. Then, the cells were centrifuged and the cell pellet was resuspended in $50 \mu 1$ of PBS. The fixed cells were incubated with $50 \mu 1$ of RNase for $30 \mathrm{~min}$ in $37^{\circ} \mathrm{C}$ water and $450 \mu \mathrm{l}$ of propidium iodide incubated for $30 \mathrm{~min}$ in the dark. The percentage of cells at a particular phase was calculated by flow cytometry.
Western blot analysis was performed to investigate the expression of P-gp. Logarithmically growing cells were exposed to various concentrations and exposure intervals of $\mathrm{As}_{2} \mathrm{O}_{3}, \mathrm{VP} 16$ and DDP. For the experiments, cells were seeded in 6-well plates at a density of $\sim 3 \times 10^{5}$ cells per milliliter at $37^{\circ} \mathrm{C}$ in a humidified incubator of $5 \%$ for $24 \mathrm{~h}$. The concentrations were based on our results of $\mathrm{IC}_{50}$ of $\mathrm{As}_{2} \mathrm{O}_{3}$, DDP and Vp16 (the concentration gradients based on the results of preliminary experiments). Each group was set in three parallel wells. $\mathrm{As}_{2} \mathrm{O}_{3} 2,3$ and $4 \mu \mathrm{M}$ (incubation 48, 72 and $96 \mathrm{~h}$ ); DDP 5, 8 and $10 \mu \mathrm{g} / \mathrm{ml}$ (incubation 12 and $24 \mathrm{~h}$ ); Vp16 50, 100 and $150 \mu \mathrm{g} / \mathrm{ml}$ (incubation 24 and $48 \mathrm{~h}$ ). After treatment with appropriate drug concentration, protein lysate was prepared in lysis buffer and the protein concentration was determined by bicinchonic acid (BCA) protein assay. Equal amount of proteins were loaded on $8 \%$ SDS-polyacrylamide gel. Voltage $80 \mathrm{~V}$ was prepared for the stacking gel; $100 \mathrm{~V}$ was prepared for separating gel in the end. The proteins were then transferred to a polyvinylidene fluoride (PVDF) membrane by semidry 

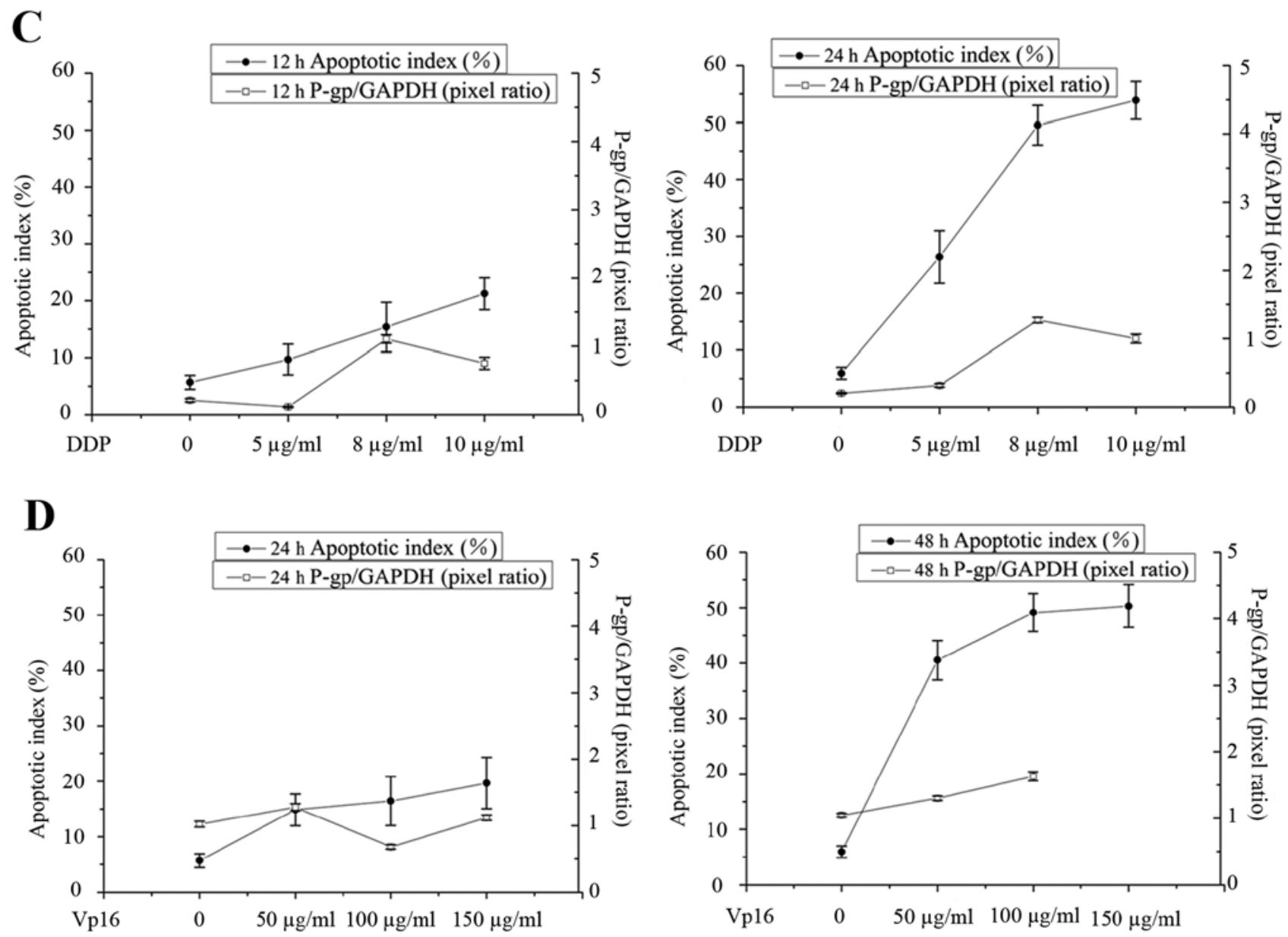

Figure 1. Continued. (C) SK-N-SH cells were cultured with varying amounts of DDP as shown. Cells were exposed to the indicated concentrations of DDP for 12 and $24 \mathrm{~h}$ and exhibit increased expression levels of P-gp. (D) Cells were exposed to the indicated concentrations of VP16 for 24 and $48 \mathrm{~h}$ and exhibit increased expression levels of P-gp. The experiment described is one representative experiment of three.

transfer system. After blocking the non-specific space of the membrane with $5 \%$ non-fat milk in TBST (TBS with $0.1 \%$ Tween-20) for one hour, membranes were first incubated with monoclonal antibody against P-glycoprotein $(1: 1,000)$ (Cell Signaling Technology) overnight at $4^{\circ} \mathrm{C}$ with constant shaking. Then the membranes were incubated with horseradish peroxidase-conjugated secondary antibody $(1: 1,000)$ (Sigma Chemical Co.) for $1 \mathrm{~h}$ with constant shaking. After electrophoresis, proteins were transferred to a nitrocellulose membrane and probed by corresponding antibodies. The quantification of protein levels in each sample was performed by ImageJ software. All experiments were performed in triplicate unless otherwise noted.

Statistical analysis. Each apoptosis value represents the mean \pm SD. Subsequently, each experiment was performed at least three times. Statistical analysis of data was carried out using a one-way ANOVA and a probability value of $<0.05(\mathrm{P}<0.05)$ was accepted as a significant difference. Computations were performed using SPSS17 software.

\section{Results}

Effects of $\mathrm{As}_{2} \mathrm{O}_{3}, \mathrm{DDP}$ and Vp16 on $\mathrm{SK}-\mathrm{N}-\mathrm{SH}$ cells. To characterize the effects of $\mathrm{As}_{2} \mathrm{O}_{3}$, DDP and Vp16 on SK-N-SH cells, we performed flow cytometry analyses of the viability of SK-N-SH cells. It has previously been shown that $\mathrm{As}_{2} \mathrm{O}_{3}$ efficiently induces apoptosis of human NB cells in vitro. The initial experiments were conducted for evaluation of $\mathrm{As}_{2} \mathrm{O}_{3}$, DDP and Vp16 induced anti-proliferation in SK-N-SH cell lines. SK-N-SH cells were treated with either PBS or drugs in each well. At first, according to the literature review and the results of our previous study, we determined the treatment conditions (drug concentration and treatment duration). The growth inhibitory effects of various concentrations of $\mathrm{As}_{2} \mathrm{O}_{3}$, DDP and Vp16 were determined as described in Materials and methods. The viability of the cells was measured at different therapy times. Each point represents the mean $\pm \mathrm{SD}$ of three independent experiments. The $\mathrm{IC}_{50}$ values were determined by FACS.

$\mathrm{As}_{2} \mathrm{O}_{3}$ exhibited dose- and time-dependent inhibitory effects on SK-N-SH cells with an $\mathrm{IC}_{50}$ of $3 \mu \mathrm{M}$ (Fig. $1 \mathrm{~A}$ and $\mathrm{B}$ ). Furthermore, these results also indicated that $\mathrm{As}_{2} \mathrm{O}_{3}$ exerted its cytotoxic effect in SK-N-SH cells via induction of apoptosis. For example, without the $\mathrm{As}_{2} \mathrm{O}_{3}$ treatment, there were only $6.9 \pm 1.3 \%$ apoptotic cells in the SK-N-SH cell line, but the apoptotic cells were gradually increased and reached $49.51 \pm 4.27 \%$ with a $3 \mu \mathrm{M}$ concentration of $\mathrm{As}_{2} \mathrm{O}_{3}$ at $72 \mathrm{~h}$ of exposure. As shown in Fig. 1A and B, only $40.77 \%$ of cells were apoptotic at $2 \mu \mathrm{M} \mathrm{As}_{2} \mathrm{O}_{3}$ of exposure, $49.51 \%$ of cells 
A
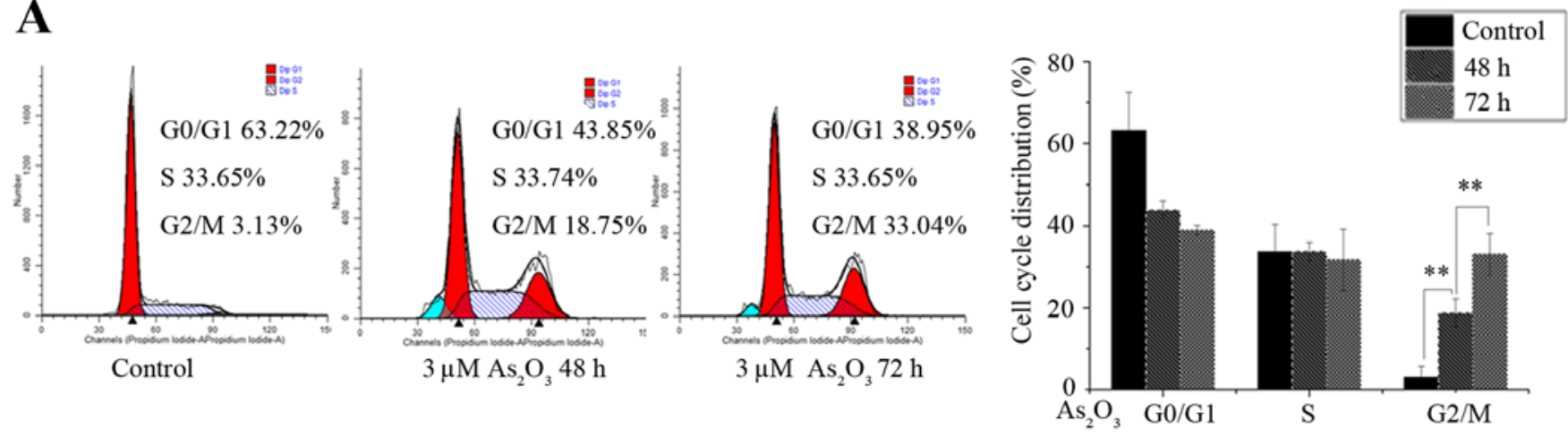

B
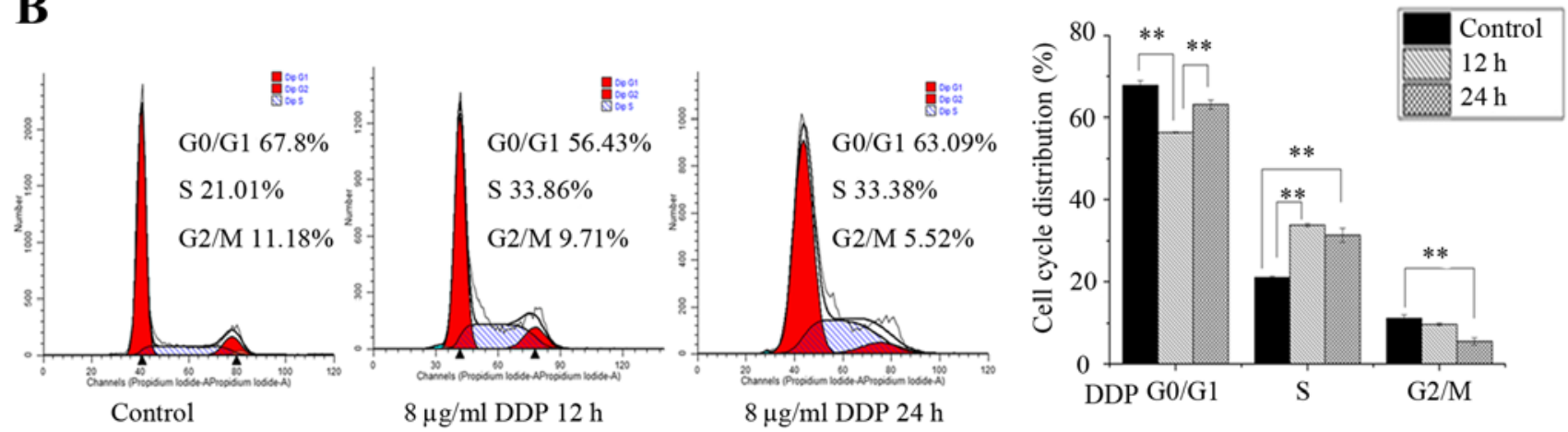

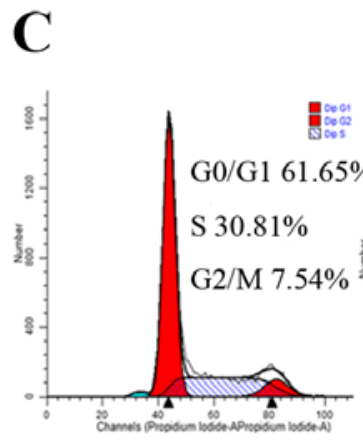

Control

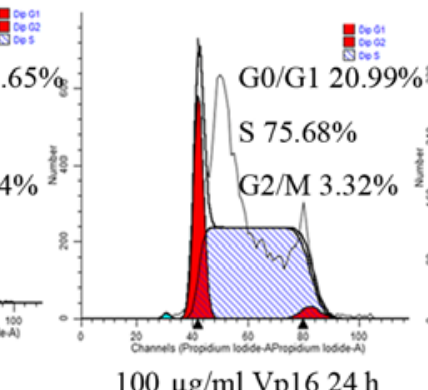

$100 \mu \mathrm{g} / \mathrm{ml} \mathrm{Vp} 1624 \mathrm{~h}$

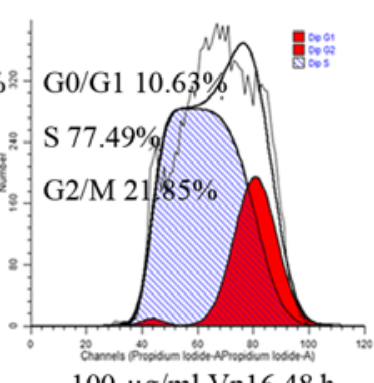

$100 \mu \mathrm{g} / \mathrm{ml} \mathrm{Vp} 1648 \mathrm{~h}$

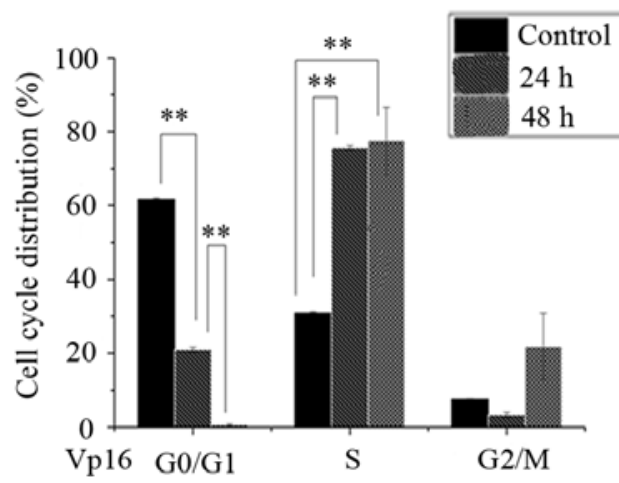

Figure 2. Cell cycle distribution analysis. One representative image of three is shown. (A) After 48- and 72-h exposure to $3 \mu \mathrm{M}$ As $\mathrm{O}_{3}$, estimation of cell cycle distribution was determined by flow cytometry. SK-N-SH cells accumulate in G2/M phase in a dose-dependent manner. All data are expressed as mean \pm SEM from three independent experiments. (B and C) SK-N-SH cells arrest in S phase after exposure to DDP and VP16. ${ }^{* *} \mathrm{P}<0.05$ a significant difference between the two groups.

were apoptotic at $3 \mu \mathrm{M} \mathrm{As}{ }_{2} \mathrm{O}_{3}$, and $54.21 \%$ were apoptotic at $4 \mu \mathrm{M} \mathrm{As}{ }_{2} \mathrm{O}_{3}$ after $72 \mathrm{~h}$ of exposure. Thus, the concentrations of $\mathrm{As}_{2} \mathrm{O}_{3}(2-4 \mu \mathrm{M})$ were the doses chosen for subsequent experiments. Moreover, flow cytometry analysis of $\mathrm{As}_{2} \mathrm{O}_{3}$-treated cells revealed that following treatment with $\mathrm{As}_{2} \mathrm{O}_{3}(3 \mu \mathrm{M})$ for 48 and $72 \mathrm{~h}$, the percentage of apoptotic cells increased from $27.87 \pm 4.47$ to $49.51 \pm 4.27 \% ; \mathrm{As}_{2} \mathrm{O}_{3}(4 \mu \mathrm{M})$ for 48 and $72 \mathrm{~h}$, the percentage of apoptotic cells increased from $31.92 \pm 2.97$ to $54.21 \pm 3.82 \%$. These data suggest that $\mathrm{As}_{2} \mathrm{O}_{3}$ may inhibit NB growth in vitro.

The growth and survival of SK-N-SH cells were markedly inhibited by the DDP and Vp16 treatment in a dose- and time-dependent manner (Fig. 1C and D). Fig. 1C and D demonstrate the results of flow cytometry with Annex in V-PI staining on SK-N-SH cells for $\mathrm{IC}_{50}$ of DDP and Vp16 found to be 8 and $100 \mu \mathrm{g} / \mathrm{ml}$; consistent with our previous results.
DDP significantly reduced SK-N-SH cell viability at concentrations of $8 \mu \mathrm{g} / \mathrm{ml}$ or more (Fig. 1C). By 24-h treatment high levels of apoptosis were observed in SK-N-SH cells.

At $8 \mu \mathrm{g} / \mathrm{ml}$, DDP strongly reduced the viability of SK-N-SH cells compared with the effects at $5 \mu \mathrm{g} / \mathrm{ml}$ (Fig. 1C) for 12 and $24 \mathrm{~h}$. Essentially the same results were obtained in previous research results. After 5, 8 and $10 \mu \mathrm{g} / \mathrm{ml}$ DDP treatment of SK-N-SH cells for $12 \mathrm{~h}$, the apoptosis rates were $(9.68 \pm 2.69) \%$, $(15.38 \pm 4.36) \%$ and $(21.25 \pm 2.82) \%$; after 5, 8 and $10 \mu \mathrm{g} / \mathrm{ml}$ DDP treatment of SK-N-SH cells for $24 \mathrm{~h}$, the apoptosis rates were $(26.37 \pm 4.6) \%,(49.55 \pm 2.48) \%$ and $(53.89 \pm 3.31) \%$, DDP cytotoxity to SK-N-SH cells in a concentration-dependent manner. The apoptosis rates significantly increased after the same concentration of DDP treatment of SK-N-SH cells for $24 \mathrm{~h}$ relative to $12 \mathrm{~h}$, DDP cytotoxity to SK-N-SH cells in a time-dependent manner. 

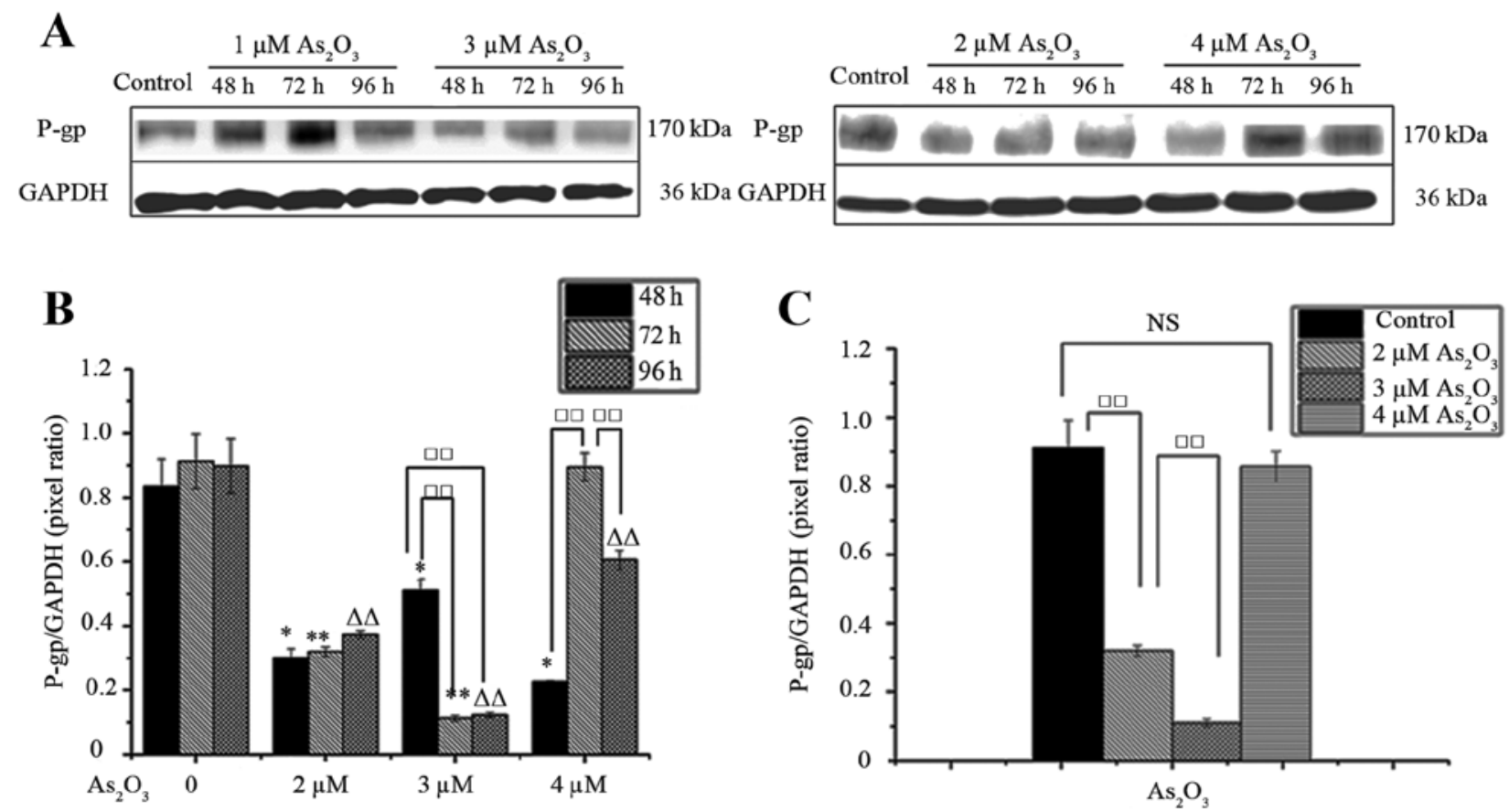

Figure 3. $\mathrm{As}_{2} \mathrm{O}_{3}$ inhibits multidrug resistant-related P-gp expression in SK-N-SH cell lines. (A) Expression levels of P-gp were detected in SK-N-SH cell lines by western blotting. $\mathrm{As}_{2} \mathrm{O}_{3}$ has decreased P-gp expression relative to the controls. Detection of GAPDH was used as a loading control. (B) The histogram shows quantifications of western blot analyses obtained with ImageQuant 5.2 software. Bars are expressed as mean \pm SEM. (C) Cells expressing P-gp show no alterations in control and $4 \mu \mathrm{M} \mathrm{As}_{2} \mathrm{O}_{3}$ for $72 \mathrm{~h}$. ${ }^{*} \mathrm{P}<0.05$, compared with $48 \mathrm{~h}$ control. ${ }^{* *} \mathrm{P}<0.05$, compared with $72 \mathrm{~h}$ control. ${ }^{\Delta \Delta} \mathrm{P}<0.05$, compared with $96 \mathrm{~h}$ control. ${ }^{\square} \mathrm{P}<0.05$, compared with the two groups. ${ }^{\mathrm{NS}} \mathrm{P}>0.05$, compared with the two groups.

After 50, 100 and $150 \mu \mathrm{g} / \mathrm{ml} \mathrm{Vp16} \mathrm{(Fig.} \mathrm{1D)} \mathrm{treatment} \mathrm{of}$ SK-N-SH cells for $48 \mathrm{~h}$, the apoptosis rates were $(14.86 \pm 2.86) \%$, $(16.44 \pm 4.41) \%$ and $(19.67 \pm 4.62) \%$; after 50,100 and $150 \mu \mathrm{g} / \mathrm{ml}$ Vp16 treatent of SK-N-SH cells for $72 \mathrm{~h}$, the apoptosis rates were $(40.54 \pm 3.53) \%,(49.12 \pm 3.96) \%$ and $(53.78 \pm 3.85) \%$, Vp16 cytotoxity to SK-N-SH cells in a concentration-dependent manner. The apoptosis rates significantly increased after the same concentration of Vp16 treatent of SK-N-SH cells for $48 \mathrm{~h}$ relative to $24 \mathrm{~h}, \mathrm{Vp} 16$ cytotoxity to SK-N-SH cells in a timedependent manner.

Effect of $\mathrm{As}_{2} \mathrm{O}_{3}, \mathrm{DDP}$ and Vp16 on cell cycle arrest of $\mathrm{SK}-\mathrm{N}-\mathrm{SH}$ cells. Analysis of cell cycle phase distribution was carried out to study the anti-proliferative mechanism of $\mathrm{As}_{2} \mathrm{O}_{3}$ on SK-N-SH cells. $\mathrm{IC}_{50}$ of $\mathrm{As}_{2} \mathrm{O}_{3}$ was added to the experimental group. According to the literature (28) and our result of $\mathrm{IC}_{50}$ of $\mathrm{As}_{2} \mathrm{O}_{3}$ on SK-N-SH cells, we chose $3 \mu \mathrm{M} \mathrm{As}_{2} \mathrm{O}_{3}$-treated SK-N-SH cells for 48 and $72 \mathrm{~h}$. $\mathrm{IC}_{50}$ of DDP and Vp16 were added to the drug control groups. According to our prior research, we chose $8 \mu \mathrm{g} / \mathrm{ml}$ DDP-treated cells for 12 and $24 \mathrm{~h}, 100 \mu \mathrm{g} / \mathrm{ml}$ Vp16-treated cells for 24 and $48 \mathrm{~h}$. Each group was set in three parallel wells. The result indicated that $\mathrm{As}_{2} \mathrm{O}_{3}$ inhibited the cell proliferation of SK-N-SH cells was partly due to the cell cycle arrest, not only cytotoxic effect.

$\mathrm{As}_{2} \mathrm{O}_{3}$ treatment resulted in a time-dependent accumulation of SK-N-SH cells in the G2/M phase (Fig. 2A). At time 0, only $3.13 \pm 2.6 \%$ of cells were in the $\mathrm{G} 2 / \mathrm{M}$ phase. After $48 \mathrm{~h}$ of treatment, $18.75 \pm 3.44 \%$ of cells were in the $\mathrm{G} 2 / \mathrm{M}$ phase. The value of $\mathrm{G} 2 / \mathrm{M}$ phase cells peaked at $72 \mathrm{~h}(33.04 \%)$.

As shown in Fig. 2B, 21.01 $\pm 0.35 \%$ of cells were at S-phase at time 0 and $33.86 \pm 0.39 \%$ of cells were at S-phase at $12 \mathrm{~h}$.
Treatment with DDP for $24 \mathrm{~h}$ caused a small decrease in the S peak in SK-N-SH cells, with no statistical difference. Treatment with Vp16 showed similar results in SK-N-SH cells (Fig. 2C). S-phase cells reached peak value $(77.49 \pm 9.08)$ at $48 \mathrm{~h}$.

Effects of $\mathrm{As}_{2} \mathrm{O}_{3}, \mathrm{DDP}$ and Vp16 on the expression changes of $P$-gp in SK-N-SH cells. Overexpression of P-gp as a membranebound energy-dependent efflux pump, in neoplastic tissue is responsible for MDR formation. Correspondingly, it has been reported that $\mathrm{As}_{2} \mathrm{O}_{3}$ inhibits the P-gp expression of leukemia cells (29). To examine whether $\mathrm{As}_{2} \mathrm{O}_{3}$, DDP and Vp16 affect $\mathrm{P}$-gp expression in SK-N-SH cells, we initially monitor the expression of P-gp at various time-points and various concentrations using western blotting. The concentrations were based on our results of $\mathrm{IC}_{50}$ of $\mathrm{As}_{2} \mathrm{O}_{3}$, DDP and $\mathrm{Vp} 16$ (the concentration gradients based on the results of preliminary experiments). Each group was set in three parallel wells.

As shown in Fig. 3A and B, western blotting revealed that $\mathrm{As}_{2} \mathrm{O}_{3}$ treatment did not result in a time- and dose-dependent upregulation of $\mathrm{P}-\mathrm{gp}(\mathrm{P}<0.05)$. To determine the extent of the observed striking reduction in P-gp expression, we performed western blot analysis on P-gp expression using the column chart (Fig. 3B). We found that 2 and $3 \mu \mathrm{M} \mathrm{As}_{2} \mathrm{O}_{3}$ treatment for 48, 72 and $96 \mathrm{~h}$ leads to reduced expression of P-gp (Fig. 3B), and the expression levels of P-gp were downregulated in $3 \mu \mathrm{M} \mathrm{As}_{2} \mathrm{O}_{3}$ treatment for $72 \mathrm{~h}$ more notably than in $2 \mu \mathrm{M} \mathrm{As}_{2} \mathrm{O}_{3}$ for $72 \mathrm{~h}$ (Fig. 3C). $\mathrm{As}_{2} \mathrm{O}_{3}$ did not lead to decreasing levels of P-gp expression in a time- and dose-dependent manner. In particular, P-gp expression was profoundly decreased under $3 \mu \mathrm{M}\left(\mathrm{IC}_{50}\right) \mathrm{As}_{2} \mathrm{O}_{3}$ treatment for 

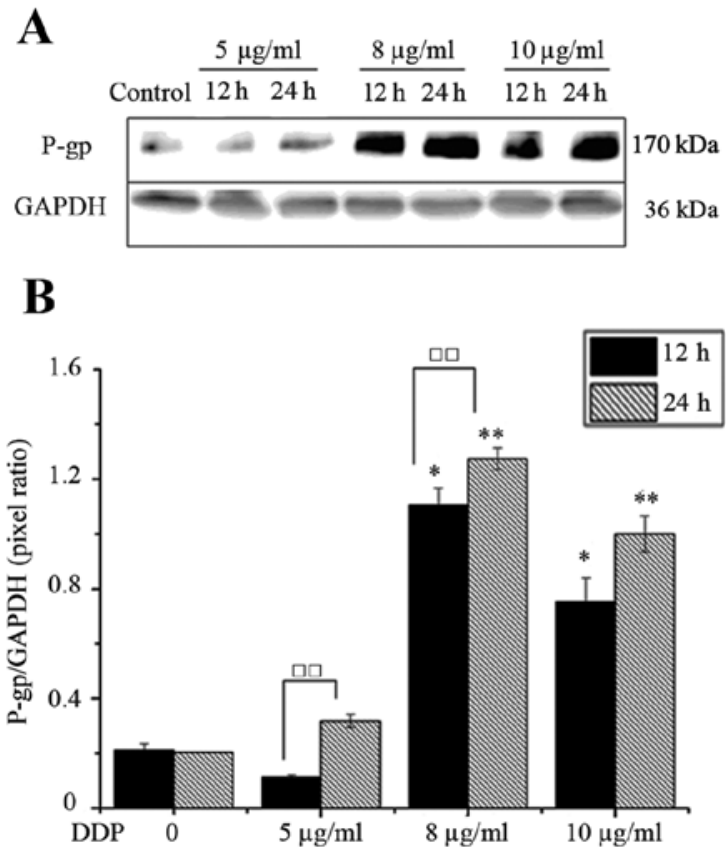

C

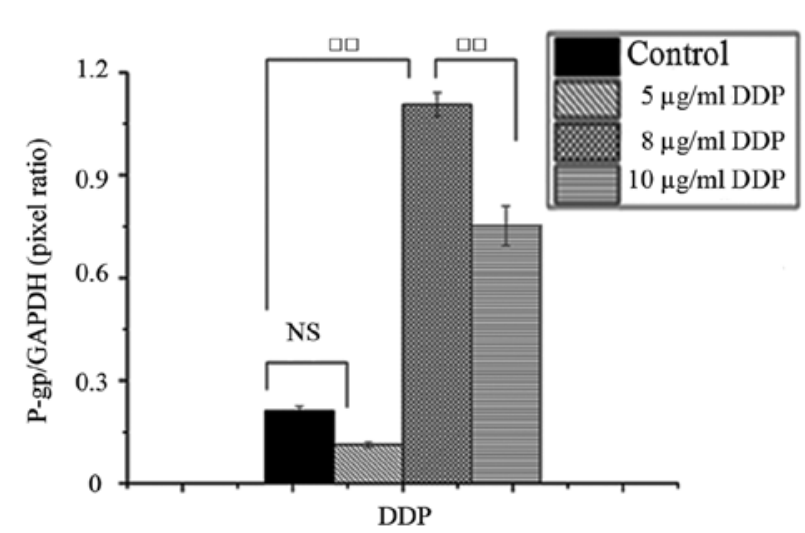

Figure 4. P-gp expression is increased by incubating the cells in the presence of DDP. (A) Western blot analysis of P-gp was performed with total cellular extracts prepared at 12 and $24 \mathrm{~h}$ after various concentrations of DDP. GAPDH was used as a control for protein loading. (B) The histogram shows quantifications of western blot analyses obtained with the ImageQuant 5.2 software. Results (mean \pm SD) are reported as relative expression normalized to GAPDH the used as loading control. (C) SK-N-SH cells were treated with various concentrations of DDP for $12 \mathrm{~h}$. P-gp appeared overexpressed in SK-N-SH cells in comparison to controls. ${ }^{*} \mathrm{P}<0.05$, compared with $12 \mathrm{~h}$ control. ${ }^{* *} \mathrm{P}<0.05$, compared with $24 \mathrm{~h}$ control. ${ }^{\Delta} \mathrm{P}<0.05$, compared with the two groups. ${ }^{\text {NS }} \mathrm{P}>0.05$, compared with the two groups.

$72 \mathrm{~h}$. At $4 \mu \mathrm{M} \mathrm{As}_{2} \mathrm{O}_{3}$ for 48 and $96 \mathrm{~h}$, the expression of P-gp was noted to gradually decrease, but no differences were found at $72 \mathrm{~h}$ after $\mathrm{As}_{2} \mathrm{O}_{3}$ exposure. Taken together, our data reveal that after $\mathrm{As}_{2} \mathrm{O}_{3}$ treatment, we observed a reproducible reduction in the induced $\mathrm{P}$-gp expression (Fig. 3B). Upon treatment with different concentrations of $\mathrm{As}_{2} \mathrm{O}_{3}$, expression of P-gp was substantially decreased (Fig. 3B). These results may imply that $\mathrm{As}_{2} \mathrm{O}_{3}$ may not be a substrate of P-gp and so it cannot stimulate and sustain the expression of P-gp in SK-N-SH cells during incubation.

On the contrary, the expression of P-gp in SK-N-SH cells was significantly retained and upregulated when treating with DDP and VP16. Western blots further identified that substantial amounts of P-gp were expressed in treatment with 8 and $10 \mu \mathrm{g} / \mathrm{ml}$ DDP for 12 and $24 \mathrm{~h}$ in comparison to the control (Fig. 4). As shown in Fig. 4B, expression levels of P-gp, were significantly lower in the same concentration of DDP for $24 \mathrm{~h}$ compared to DDP for $12 \mathrm{~h}$. Furthermore, the highest levels of $\mathrm{P}$-gp were observed in SK-N-SH cells with $\mathrm{IC}_{50}$ of DDP for $24 \mathrm{~h}$. This difference was statistically significant in $5 \mu \mathrm{g} / \mathrm{ml}$ DDP for 12 and $24 \mathrm{~h}$.

Similarly, the increase in the P-gp expression level was detected in SK-N-SH cells that were treated with Vp16 in comparison with the basal level identified in control cells (Fig. 5). Furthermore, 50 and $100 \mu \mathrm{g} / \mathrm{ml}$ of $\mathrm{Vp} 16$ for 24 and $48 \mathrm{~h}$ elicited increase over the P-gp expression in SK-N-SH cells. These histograms illustrate the pattern of the dosedependent response to various concentrations of Vp16 (Fig. 5B and C). As shown in Fig. 5B, the P-gp expression was higher in $100 \mu \mathrm{g} / \mathrm{ml} \mathrm{Vp} 16$ of $48 \mathrm{~h}$ than in $100 \mu \mathrm{g} / \mathrm{ml} \mathrm{Vp} 16$ of $24 \mathrm{~h}$. On the other hand, upon $\mathrm{IC}_{50}$ of Vp16 administration for $48 \mathrm{~h}$, the P-gp expression was the highest. The P-gp was consistently induced by $150 \mu \mathrm{g} / \mathrm{ml}$ Vp16 (Fig. 5B).

To examine whether P-gp levels correlated with apoptosis, western blot analyses and flow cytometry were performed. Our results showed that DDP and Vp16 induced apoptosis in SK-N-SH cells, and they increased the level of P-gp expression (Fig. 1C and D). In contrast, $\mathrm{As}_{2} \mathrm{O}_{3}$ in the micromolar range had a concentration-dependent toxic effect on SK-N-SH cells with decreased P-gp expression (Fig. 1B). In conclusion, this study demonstrates that $\mathrm{As}_{2} \mathrm{O}_{3}$ is efficacious in reversing P-gp-mediated MDR by inhibiting transport function and expression of P-gp.

\section{Discussion}

NB is characterised as the most common extracranial solid tumor with great malignancy that ranges from spontaneous regression in $10 \%$ of all cases to rapid and largely treatment resistant progression with fatal outcome (30). Despite treatment advances including chemotherapy, radiotherapy and stem cell transplantation, advanced NB still remains one of the most challenging problems that physicians must deal with in pediatric oncology and long-term survival rate is $<40 \%$ (6). However, much of the literature points to the fact that the prolonged treatment with chemotherapy is often ineffectual due to the appearance of MDR.

The availability of reducing MDR drugs is a prerequisite to develop novel effective therapies. Decades ago, $\mathrm{As}_{2} \mathrm{O}_{3}$ was known as a carcinogen, however, according to research at present it now becomes a hotspot in the treatment of tumors. 

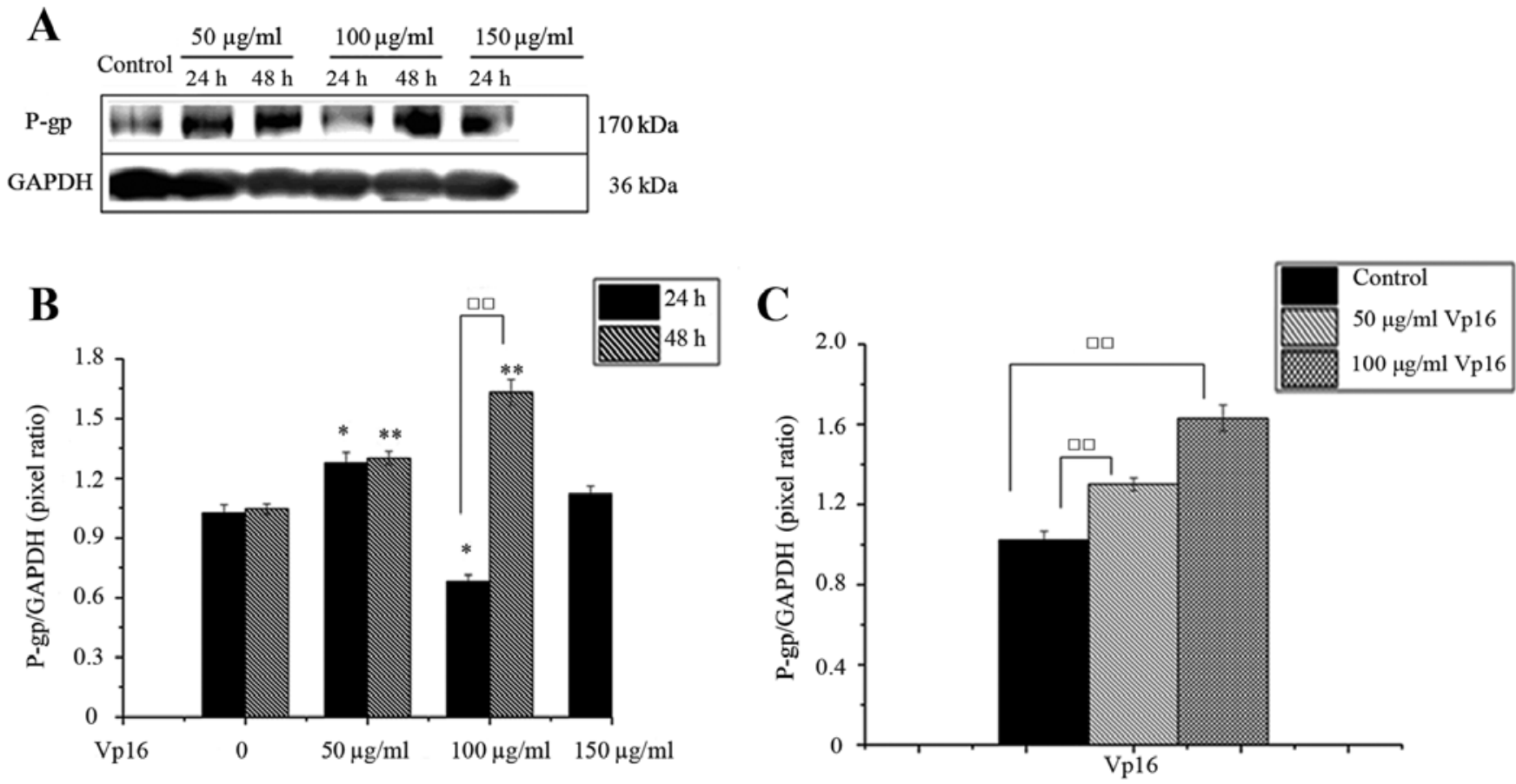

Figure 5. The VP16-inducible expression of P-gp determined by western blotting. (A) SK-N-SH cells were treated with various doses of VP16 for the indicated times. Expression levels of P-gp were detected in SK-N-SH cell lines by western blotting. GAPDH is employed as the internal control. Result is a representative image of three. P-gp expression was determined by western blotting. (B) P-gp appeared overexpressed in SK-N-SH cells. (C) SK-N-SH cells were treated with various concentrations of $\mathrm{Vp} 16$ for $48 \mathrm{~h} .{ }^{*} \mathrm{P}<0.05$, a significant difference from $24 \mathrm{~h}$ controls and ${ }^{* *} \mathrm{P}<0.05$, a significant difference from $48 \mathrm{~h}$ controls $.{ }^{\Delta \Lambda} \mathrm{P}<0.05$, compared with the two groups.

The clinical use of $\mathrm{As}_{2} \mathrm{O}_{3}$ as an anticancer agent is based on the drug's ability to induce APL cell differentiation and promotes apoptosis. $\mathrm{As}_{2} \mathrm{O}_{3}$ is a poor substrate for transport by P-glycoprotein and recommended for cancer therapy especially in reversing the MDR in vitro, such as leukemia (31), osteosarcoma (32), myeloma (33), gastric (34) and hepatic carcinoma (35). In addition, we found that $\mathrm{As}_{2} \mathrm{O}_{3}$ lacked crossresistance in both P-glycoprotein- and MRP-overexpressing cell lines (36).

$\mathrm{As}_{2} \mathrm{O}_{3}$ partially reduce MDR to DOX in K562/A02 cells via reducing function of efflux pumps such as GST-p and modulate the expression of MDR-related proteins such as Topo-II and bcl-2 (31). Although our understanding of $\mathrm{As}_{2} \mathrm{O}_{3}$ clinical treatment of MDR NB has many advantages, less is known about the effect of $\mathrm{As}_{2} \mathrm{O}_{3}$ on the P-gp expression in NB.

To address the possibility that $\mathrm{As}_{2} \mathrm{O}_{3}$ has a role in reducing drug resistance, the expression levels of P-gp were assayed by western blotting. In this study we investigated the mechanism involved in the suppression of MDR NB. We analyzed the effect of $\mathrm{As}_{2} \mathrm{O}_{3}$ on P-gp expression, in order to investigate the mechanism involved in $\mathrm{As}_{2} \mathrm{O}_{3}$ treatment of MDR NB and provide new evidence for $\mathrm{As}_{2} \mathrm{O}_{3}$ clinical treatment NB and thereby reinforcing that $\mathrm{As}_{2} \mathrm{O}_{3}$ has potential in clinical treatment of NB, contributing to reducing drug resistance. To our knowledge, this is the first demonstration of $\mathrm{As}_{2} \mathrm{O}_{3}$ directly affecting expression levels of P-gp in SK-N-SH cell lines. Therefore, our approach, which utilizes $\mathrm{As}_{2} \mathrm{O}_{3}$ and conventional chemotherapy drug treatment of NB cell lines and detects the P-gp levels, provides a more comprehensive system in which to investigate the roles of $\mathrm{As}_{2} \mathrm{O}_{3}$ in apoptosis events, ultimately leading to establishment of the possibility of $\mathrm{As}_{2} \mathrm{O}_{3}$ clinical treatment MDR NB. This is the first report characterizing the P-gp alterations in SK-N-SH cells treated with $\mathrm{As}_{2} \mathrm{O}_{3}$, DDP and VP16.

Herein, we report the effect of $\mathrm{As}_{2} \mathrm{O}_{3}$ on cytotoxicity of SK-N-SH human neuroblastoma cells in vitro. Following treatment with $\mathrm{As}_{2} \mathrm{O}_{3}$ at different low doses for $48 \mathrm{~h}$, apoptosis was observed in SK-N-SH cells, and the apoptosis rate has a positive correlation with acting time; coincident with the results of Karlsson et al (28). Our data also demonstrate that $\mathrm{As}_{2} \mathrm{O}_{3}$ is efficacious in inhibiting the proliferation of SK-N-SH cells in a dose-dependent manner, with an $\mathrm{IC}_{50}$ of $\sim 3 \mu \mathrm{M}$ following treatment with $\mathrm{As}_{2} \mathrm{O}_{3}$ for $72 \mathrm{~h}$. In this study, $\mathrm{As}_{2} \mathrm{O}_{3}$ inhibited cell viability and/or induced apoptosis in SK-N-SH cells depending on the drug concentration, suggesting that by prolonging the time of effective drug and increased the drug concentration, can significantly improve drug efficacy.

In a previous report, we first demonstrated that TrkA, TrkB and TrkC gene expression were upregulated with increasing concentration of $\mathrm{As}_{2} \mathrm{O}_{3}$ administration, more apparent at $48 \mathrm{~h}$ than $24 \mathrm{~h}$. Advanced NB tumors carrying amplified MYCN oncogene which is the most unfavorable prognostic factor and prominent genetic marker of high-stage disease often exhibit an aggressive phenotype (37). Yin et al (38) found that MYCN mRNA in LA-N-5 cell lines was strongly inhibited by treatment with different concentrations of $\mathrm{As}_{2} \mathrm{O}_{3}$, and decline the most obvious at $3 \mu \mathrm{M} \mathrm{As}_{2} \mathrm{O}_{3}$. This, together with our study, indicates that $\mathrm{As}_{2} \mathrm{O}_{3}$ may exert a greater anti-carcinogenesis effect on MYCN positive high-risk NB than other drugs. 
To overcome the limitation, one strategy is to increase doses of chemotherapy drugs; however, it causes serious toxic effects on heart, liver, kidney and hearing damage, which patients are not able to tolerate, abandoning the treatment. When $\mathrm{As}_{2} \mathrm{O}_{3}$ was combined with DDP or DOX in ALL, it showed strong synergy with chemotherapeutic agent in vitro and reversed the effect of DDP or DOX on multidrug resistance of tumor cell lines $(15,31,39)$. In fact, a number of recent publications indicate that $\mathrm{As}_{2} \mathrm{O}_{3}$ combined with DDP or DOX effect on leukemia cells lead to synergy and reverse tumor resistance. We speculate that the cytotoxic efficiency of $\mathrm{As}_{2} \mathrm{O}_{3}$ combined with conventional chemotherapy drugs, is important from a clinical point of view.

In conclusion, our data shows that the $\mathrm{IC}_{50}$ value for $\mathrm{As}_{2} \mathrm{O}_{3}$ in SK-N-SH cells was $\sim 3 \mu \mathrm{M}$, a concentration very close to clinically achievable concentration for successfully treating patients with acute promyelocytic leukemia (40). Thus it is suggested that $\mathrm{As}_{2} \mathrm{O}_{3}$ might be suitable in the treatment of some instances of NB.

Suppression of cell growth by $\mathrm{As}_{2} \mathrm{O}_{3}$ can be explained in part by its capacity to affect cell cycle distribution. Cell cycle analysis has revealed that $\mathrm{As}_{2} \mathrm{O}_{3}$ significantly induced a time-dependent accumulation of cells in the $\mathrm{G} 2 / \mathrm{M}$ phase more significantly increased $72 \mathrm{~h}$ later. Therefore, to explain the mechanism that $\mathrm{As}_{2} \mathrm{O}_{3}$ induced rapid and extensive apoptosis concomitant with arrest of cells in $\mathrm{G} 2 / \mathrm{M}$ phase of the cell cycle, due to G2/M block, unlike G1 block, is more toxic to the cells, and not sreversible. Thus $\mathrm{As}_{2} \mathrm{O}_{3}$-induced G2/M arrest may be a requirement for the activation of apoptotic pathways.

Park et al (41) showed that $\mathrm{As}_{2} \mathrm{O}_{3}$ arrest cell cycle in $\mathrm{G} 2 / \mathrm{M}$ phase in leukemia U937 cells and trigger apoptosis. Gao et al (42) showed that $\mathrm{As}_{2} \mathrm{O}_{3}$ could arrest NB4 cell lines in G2/M phase, and $\mathrm{G} 2 / \mathrm{M}$ cells which possessed higher ROS levels were more susceptible to $\mathrm{As}_{2} \mathrm{O}_{3}$-induced apoptosis (42). More strikingly, Hassani et al (43) showed that the G2/M arrest plays a critical role in the induction of apoptosis by $\mathrm{As}_{2} \mathrm{O}_{3}$ in $\mathrm{NB}$ cells.

Here, we confirmed that that $\mathrm{As}_{2} \mathrm{O}_{3}$ treatment resulted in accumulation of cells in the $\mathrm{G} 2 / \mathrm{M}$ phase in a time-dependent manner. Furthermore, activation of caspases occurred only in $\mathrm{As}_{2} \mathrm{O}_{3}$-induced mitotic cells, not in interphase cells (36), suggesting $\mathrm{As}_{2} \mathrm{O}_{3}$ has a higher cytotoxicity against NB cells blocked in $\mathrm{G} 2 / \mathrm{M}$ phase. This finding provides a more comprehensive understanding of restraining cell cycle at G2/M closely related to the initiation of apoptosis.

The exact mechanisms underlying $\mathrm{As}_{2} \mathrm{O}_{3}$ that could markedly arrest cell cycle in $\mathrm{G} 2 / \mathrm{M}$ phase are not fully understood. It is possible that $\mathrm{As}_{2} \mathrm{O}_{3}$ affects the expression of the cell cycle regulatory elements and $\mathrm{AKt}$ signal transduction pathway. The results of Han et al (44) suggest that, the levels of cdc2 protein which is related to the progression of $\mathrm{G} 2 / \mathrm{M}$ phase were downregulated in cells treated with $\mathrm{As}_{2} \mathrm{O}_{3}$. There are a variety of reports suggesting that Akt is one of the important survival factors and plays an essential role stimulating of cellular growth and chemotherapeutic resistance to apoptosis $(45,46)$. PTEN as the tumor suppressor gene inactivated in a wide variety of cancers downregulates active Akt (47) regulates many biological processes including metabolism, growth, survival, and proliferation. Data from Zhang et al (48) and $\mathrm{Li}$ et al (49) showed that $\mathrm{As}_{2} \mathrm{O}_{3}$ is associated with upregulated
Wee1 and PTEN levels and downregulated cdc 2 protein and Akt signal pathway resulting in induction of $\mathrm{G} 2 / \mathrm{M}$ cell cycle arrest.

In addition, $\mathrm{As}_{2} \mathrm{O}_{3}$ treatment blocked the cell cycle in $\mathrm{G} 1$ or at $\mathrm{G} 2 / \mathrm{M}$ depending on the cell line. We have also observed that $\mathrm{As}_{2} \mathrm{O}_{3}$ was able to induce an $\mathrm{M}$ phase arrest of the cell cycle in MCF-7, H460, HeLa and K562 cell lines (36), related with tubulin aggregation, like paclitaxel (50). Liu et al (51) reported that $\mathrm{As}_{2} \mathrm{O}_{3}$-induced $\mathrm{G} 1$ arrest in myeloma cells with wild-type (wt) p53 but G2/M arrest in myeloma cells with mutated p53. Thus $\mathrm{As}_{2} \mathrm{O}_{3}$ induces cell cycle arrest in two distinct pathways including $\mathrm{G} 1$ or $\mathrm{G} 2 / \mathrm{M}$ cell cycle arrest, depending on varying p53 status.

Here, we confirmed that $\mathrm{As}_{2} \mathrm{O}_{3}$ could markedly arrest cell cycle in $\mathrm{G} 2 / \mathrm{M}$ phase with a time-dependent manner. Furthermore, activation of caspases occurred only in $\mathrm{As}_{2} \mathrm{O}_{3}$-induced mitotic cells, not in interphase cells (36), suggesting $\mathrm{As}_{2} \mathrm{O}_{3}$ has a higher cytotoxicity against NB cells blocked in $\mathrm{G} 2 / \mathrm{M}$ phase. This finding provides a more comprehensive understanding of $\mathrm{As}_{2} \mathrm{O}_{3}$-induced mitotic arrest closely related to the initiation of apoptotic pathways. Taken together, our data demonstrate that $\mathrm{As}_{2} \mathrm{O}_{3}$ markedly arrests cell cycle at $\mathrm{G} 2 / \mathrm{M}$ phase, and induces apoptosis. Our study on cell cycle revealed that $\mathrm{As}_{2} \mathrm{O}_{3}$ causes accumulation of SK-N-SH cells in the G2/M phase, in rational combinatorial strategies involving $\mathrm{As}_{2} \mathrm{O}_{3}$ in combination with vinorelbine (NVB) that $\mathrm{G} 2 / \mathrm{M}$ phase is sensitive to and might clinically intensify $\mathrm{As}_{2} \mathrm{O}_{3}$-induced apoptosis.

Currently, the overexpression of membrane proteins in cancer cells functioning as drug pumbs results in MDR to chemotherapeutic agents is a major impediment to the successful treatment of cancer. The adenosine triphosphate (ATP)-binding cassette (ABC) membrane transporter family is well known including ABCB1 (P-glycoprotein, P-gp), ABCC1 (multidrug-resistant protein 1, MRP1), ABCC2 (MRP2) and ABCG2 (breast cancer resistance protein, $\mathrm{BCRP}$ ). As far as is know, multidrug resistance $\mathrm{P}$-glycoprotein, an ABCB1 member of the ABC transporter family, acts as a membrane-bound energy-dependent efflux pump lowering intracellular drug levels to sublethal concentrations and helps cells to escape from death. P-gp which pumps a broad range of structurally unrelated cells encoded by the MDR1 gene, overexpression of it in neoplastic tissue is responsible for the emergence of the MDR phenotype in cancer cells. P-gp has a basal ATPase activity and can be activated in the presence of its substrates such as commonly used chemotherapy drugs of VCR, DOX and Vp16, then expelling antitumor agents from the cytoplasm by ATP hydrolysis (52). Overexpression of P-gp confers reduced sensitivity to large group of cytotoxic drugs.

It is generally believed that the overexpression of P-gp pumping out intracellular commonly used chemotherapy drugs in NB chemotherapy regiments such as anthracycline, epipodophyllotoxin and vinca alkaloids, leads to NB developing MDR. Gibalová et al (53) indicated that P-gp, independent of its drug efflux activity as DDP is not transportable by P-gp, altering DDP-induced apoptosis pathway of a decrease in DDP-induced caspase-3 activation that confers a partial loss of DDP sensitivity. Moreover, Topo-II (54) and glutathione S-transferase $\pi$ (GST $\pi$ ) (55) overexpression 
contributes to MDR formation. In contrast, acumulating evidence indicates that P-gp has an antiapoptotic function by pumping some caspase-dependent apoptotic substance and toxic chemicals $(56,57)$.

Up to now, the regulatory mechanisms underlying the expression of P-gp have not yet been well clarified. Duraj et al (58) verified that that mitogen-activated protein kinase (MAPK) pathway was associated with regulatory P-gp expression in P-gp-mediated MDR. In addition, Wei et al (52) demonstrated that tetrandrine, an inhibitor of MAPK pathway, effectively reverses the MDR of KBv200 and MCF-7/adr cells presumably via downregulating P-gp expression of SK-N-SH. In addition, the hepatocarcinogen 2-acetylaminofluorene 2-AAF could also upregulate the human MDR1 expression in human hepatoma (59). Zhou et al (60) provided the first direct evidence that the c-Jun NH 2-terminal kinase (JNK) pathway could indeed downregulate P-glycoprotein in a dose- and time-dependent manner, and reverses P-glycoprotein mediated MDR in cancer cells.

Although $\mathrm{As}_{2} \mathrm{O}_{3}$ had potent reversal effect on leukemia cell P-gp-mediated MDR in vitro (29), little information is available regarding this compound's effect on the P-gp expression in NB cells. Our study aims to verify that. We actually did observe that $\mathrm{As}_{2} \mathrm{O}_{3}$ inhibited $\mathrm{P}$-gp expression in SK-N-SH cells. In particular, P-gp protein levels were strongly decreased with 2 and $3 \mu \mathrm{M} \mathrm{As}_{2} \mathrm{O}_{3}$ for 48,72 and $96 \mathrm{~h}$. The data in this study showed upregulation of P-gp on SK-N-SH cells following treatment with DDP or VP16, which is consistent with Gu et al (61) and Yang and Page (62). Collectively, our result showed high levels of P-gp observed when SK-N-SH cells were treated with DDP and Vp16, however, P-gp expression is strongly reduced upon treatment with different concentrations of $\mathrm{As}_{2} \mathrm{O}_{3}$. It is therefore very likely that appropriately increased $\mathrm{As}_{2} \mathrm{O}_{3}$ accumulation and acting time, P-gp expression would not be upregulated. In general, the results presented in this study indicate $\mathrm{As}_{2} \mathrm{O}_{3}$ is a poor substrate for transport by P-glycoprotein, suggesting that $\mathrm{As}_{2} \mathrm{O}_{3}$ may be useful for treatment of human solid tumors, particularly in patients with MDR. There is evidence that decreasing protein expression level of P-gp is one of the effective ways to reverse P-gp-mediated MDR (52).

Therefore, these findings support the notion that inhibition of P-gp expression may reverse the MDR phenotype through enhancing intracellular accumulation of anticancer drugs. To circumvent MDR, much effort has focused on finding P-gp inhibitors and identification of molecules targeting multiple drug-resistant mechanisms to effectively reverse P-gpmediated MDR. However, the failure of this type of drugs with poor clinical effectiveness has substantially dampened the initial enthusiasm. One reasonable explanation is the side-effects of these drugs which now has affected its wide application in the clinic.

In conclusion, $\mathrm{As}_{2} \mathrm{O}_{3}$ inhibited the growth of SK-N-SH cells by inducing a $\mathrm{G} 2 / \mathrm{M}$ arrest of the cell cycle and by triggering apoptosis. These findings demonstrated that $\mathrm{As}_{2} \mathrm{O}_{3}$ is effective and a potential agent in reversing P-gp-mediated MDR. Our results support $\mathrm{As}_{2} \mathrm{O}_{3}$ as an effective complement to conventional chemotherapy for high-risk NB patients and possibly also for potential use for reversing P-gp-mediated MDR when synergistic with chemotherapy.

\section{Acknowledgements}

This study was supported by grant 2014A030313024 from the Guang Dong Natural Science Foundation; grant from the Guangdong Science and Technology Department (2015B050501004).

\section{References}

1. Li T, Cui ZB, Ke XX, Tan J, Li FF, Li T, Wang XW and Cui HJ: Essential role for p53 and caspase-9 in DNA damaging druginduced apoptosis in neuroblastoma IMR32 cells. DNA Cell Biol 30: 1045-1050, 2011.

2. Wolter J, Angelini P and Irwin M: p53 family: Therapeutic targets in neuroblastoma. Future Oncol 6: 429-444, 2010.

3. Cohn SL, Pearson AD, London WB, Monclair T, Ambros PF, Brodeur GM, Faldum A, Hero B, Iehara T, Machin D, et al; INRG Task Force: The International Neuroblastoma Risk Group (INRG) classification system: An INRG Task Force report. J Clin Oncol 27: 289-297, 2009.

4. Sato Y, Kurosawa H, Sakamoto S, Kuwashima S, Hashimoto T, Okamoto K, Tsuchioka T, Fukushima K and Arisaka O: Usefulness of ${ }^{18} \mathrm{~F}$-fluorodeoxyglucose positron emission tomography for follow-up of 13-cis-retinoic acid treatment for residual neuroblastoma after myeloablative chemotherapy. Medicine (Baltimore) 94: e1290, 2015.

5. Yu AL, Gilman AL, Ozkaynak MF, London WB, Kreissman SG, Chen HX, Smith M, Anderson B, Villablanca JG, Matthay KK, et al; Children's Oncology Group: Anti-GD2 antibody with GM-CSF, interleukin-2, and isotretinoin for neuroblastoma. N Engl J Med 363: 1324-1334, 2010.

6. Lim JY, Kim YS, Kim KM, Min SJ and Kim Y: B-carotene inhibits neuroblastoma tumorigenesis by regulating cell differentiation and cancer cell stemness. Biochem Biophys Res Commun 450: 1475-1480, 2014.

7. Pettersson HM, Karlsson J, Pietras A, Øra I and Påhlman S: Arsenic trioxide and neuroblastoma cytotoxicity. J Bioenerg Biomembr 39: 35-41, 2007.

8. Keshelava N, Davicioni E, Wan Z, Ji L, Sposto R, Triche TJ and Reynolds CP: Histone deacetylase 1 gene expression and sensitization of multidrug-resistant neuroblastoma cell lines to cytotoxic agents by depsipeptide. J Natl Cancer Inst 99: 1107-1119, 2007.

9. Yonehara A, Tanaka Y, Kulkeaw K, Era T, Nakanishi Y and Sugiyama D: Aloe vera extract suppresses proliferation of neuroblastoma cells in vitro. Anticancer Res 35: 4479-4485, 2015.

10. Goldsmith KC and Hogarty MD: Targeting programmed cell death pathways with experimental therapeutics: Opportunities in high-risk neuroblastoma. Cancer Lett 228: 133-141, 2005.

11. Street CA, Routhier AA, Spencer C, Perkins AL, Masterjohn K, Hackathorn A, Montalvo J, Dennstedt EA and Bryan BA: Pharmacological inhibition of Rho-kinase (ROCK) signaling enhances cisplatin resistance in neuroblastoma cells. Int $\mathbf{J}$ Oncol 37: 1297-1305, 2010.

12. Qiu YY, Mirkin BL and Dwivedi RS: Inhibition of DNA methyltransferase reverses cisplatin induced drug resistance in murine neuroblastoma cells. Cancer Detect Prev 29: 456-463, 2005.

13. Pajic M, Norris MD, Cohn SL and Haber M: The role of the multidrug resistance-associated protein 1 gene in neuroblastoma biology and clinical outcome. Cancer Lett 228: 241-246, 2005.

14. Huang JM, Sheard MA, Ji L, Sposto R and Keshelava N: Combination of vorinostat and flavopiridol is selectively cytotoxic to multidrug-resistant neuroblastoma cell lines with mutant TP53. Mol Cancer Ther 9: 3289-3301, 2010.

15. Iwasaki I, Sugiyama H, Kanazawa S and Hemmi H: Establishment of cisplatin-resistant variants of human neuroblastoma cell lines, TGW and GOTO, and their drug cross-resistance profiles. Cancer Chemother Pharmacol 49: 438-444, 2002.

16. Gillet JP, Efferth T and Remacle J: Chemotherapy-induced resistance by ATP-binding cassette transporter genes. Biochim Biophys Acta 1775: 237-262, 2007.

17. Gesundheit B, Malach L, Or R and Hahn T: Neuroblastoma cell death is induced by inorganic arsenic trioxide (As (2)O (3)) and inhibited by a normal human bone marrow cell-derived factor. Cancer Microenviron 1: 153-157, 2008. 
18. Au WY, Li CK, Lee V, Yuen HL, Yau J, Chan GC, Ha SY and Kwong YL: Oral arsenic trioxide for relapsed acute promyelocytic leukemia in pediatric patients. Pediatr Blood Cancer 58: 630-632, 2012

19. Iland HJ, Bradstock K, Supple SG, Catalano A, Collins M, Hertzberg M, Browett P, Grigg A, Firkin F, Hugman A, et al; Australasian Leukaemia and Lymphoma Group: All-transretinoic acid, idarubicin, and IV arsenic trioxide as initial therapy in acute promyelocytic leukemia (APML4). Blood 120: 1570-1580, quiz 1752, 2012.

20. Haga N, Fujita $\mathrm{N}$ and Tsuruo T: Involvement of mitochondrial aggregation in arsenic trioxide $\left(\mathrm{As}_{2} \mathrm{O}_{3}\right)$-induced apoptosis in human glioblastoma cells. Cancer Sci 96: 825-833, 2005.

21. Pettersson HM, Pietras A, Munksgaard Persson M, Karlsson J, Johansson L, Shoshan MC and Påhlman S: Arsenic trioxide is highly cytotoxic to small cell lung carcinoma cells. Mol Cancer Ther 8: 160-170, 2009.

22. Lallemand-Breitenbach V, Zhu J, Chen $\mathrm{Z}$ and de Thé H: Curing APL through PML/RARA degradation by $\mathrm{As}_{2} \mathrm{O}_{3}$. Trends Mol Med 18: 36-42, 2012.

23. Woo SY, Lee MY, Jung YJ, Yoo ES, Seoh JY, Shin HY, Ahn HS and Ryu KH: Arsenic trioxide inhibits cell growth in SH-SY5Y and SK-N-AS neuroblastoma cell lines by a different mechanism. Pediatr Hematol Oncol 23: 231-243, 2006.

24. Kim DW, Ahan SH and Kim TY: Enhancement of arsenic trioxide $(\mathrm{As}(2) \mathrm{O}(3))$-mediated apoptosis using berberine in human neuroblastoma SH-SY5Y Cells. J Korean Neurosurg Soc 42: 392-399, 2007.

25. Florea AM, Splettstoesser F and Büsselberg D: Arsenic trioxide $\left(\mathrm{As}_{2} \mathrm{O}_{3}\right)$ induced calcium signals and cytotoxicity in two human cell lines: SY-5Y neuroblastoma and 293 embryonic kidney (HEK). Toxicol Appl Pharmacol 220: 292-301, 2007.

26. Karlsson J, Edsjö A, Påhlman S and Pettersson HM: Multidrugresistant neuroblastoma cells are responsive to arsenic trioxide at both normoxia and hypoxia. Mol Cancer Ther 4: 1128-1135, 2005.

27. Ryu KH, Woo SY, Lee MY, Jung YJ, Yoo ES, Seoh JY, Kie JH, Shin HY and Ahn HS: Morphological and biochemical changes induced by arsenic trioxide in neuroblastoma cell lines. Pediatr Hematol Oncol 22: 609-621, 2005

28. Karlsson J, Øra I, Pörn-Ares I and Påhlman S: Arsenic trioxideinduced death of neuroblastoma cells involves activation of Bax and does not require p53. Clin Cancer Res 10: 3179-3188, 2004.

29. Qian XP, Liu BR, Yin HT, Wang LF, Zou ZY and Du J: Effect of arsenic trioxide on drug transporting molecules in acute promyelocytic leukemia cell line. Zhonghua Zhong Liu Za Zhi 26: 601-605, 2004 (In Chinese).

30. Lang WH and Sandoval JA: Detection of PI3K inhibition in human neuroblastoma using multiplex luminex bead immunoassay: A targeted approach for pathway analysis. J Biomol Screen 19: 1235-1245, 2014.

31. Zhao D, Jiang Y, Dong X, Liu Z, Qu B, Zhang Y, Ma N and Han Q: Arsenic trioxide reduces drug resistance to adriamycin in leukemic K562/A02 cells via multiple mechanisms. Biomed Pharmacother 65: 354-358, 2011.

32. Zhao H, Guo W, Peng C, Ji T and Lu X: Arsenic trioxide inhibits the growth of adriamycin resistant osteosarcoma cells through inducing apoptosis. Mol Biol Rep 37: 2509-2515, 2010.

33. Abeltino M, Bonomini S, Bolzoni M, Storti P, Colla S, Todoerti K, Agnelli L, Neri A, Rizzoli V and Giuliani N: The proapoptotic effect of zoledronic acid is independent of either the bone microenvironment or the intrinsic resistance to bortezomib of myeloma cells and is enhanced by the combination with arsenic trioxide. Exp Hematol 39: 55-65, 2011.

34. Xue YW, Han JG, Li BX and Yang BF: Reversal effect and mechanism of arsenic trioxide on multidrug resistance of gastric carcinoma cells SGC7901. Yao Xue Xue Bao 42: 949-953, 2007 (In Chinese)

35. Chan JY, Siu KP and Fung KP: Effect of arsenic trioxide on multidrug resistant hepatocellular carcinoma cells. Cancer Lett 236: 250-258, 2006.

36. Ling YH, Jiang JD, Holland JF and Perez-Soler R: Arsenic trioxide produces polymerization of microtubules and mitotic arrest before apoptosis in human tumor cell lines. Mol Pharmacol 62: 529-538, 2002.

37. Paffhausen T, Schwab M and Westermann F: Targeted MYCN expression affects cytotoxic potential of chemotherapeutic drugs in neuroblastoma cells. Cancer Lett 250: 17-24, 2007.
38. Yin H, Tang SQ and Zhao QY: Effect of arsenic trioxide on MYCN mRNA expression in neuroblastoma cells. Shandong Med J 37: 57-58, 2008.

39. D'Aguanno S, D'Alessandro A, Pieroni L, Roveri A, Zaccarin M, Marzano V, De Canio M, Bernardini S, Federici G and Urbani A: New insights into neuroblastoma cisplatin resistance: A comparative proteomic and meta-mining investigation. J Proteome Res 10: 416-428, 2011.

40. Shen ZX, Chen GQ, Ni JH, Li XS, Xiong SM, Qiu QY, Zhu J, Tang W, Sun GL, Yang KQ, et al: Use of arsenic trioxide $\left(\mathrm{As}_{2} \mathrm{O}_{3}\right)$ in the treatment of acute promyelocytic leukemia (APL): II. Clinical efficacy and pharmacokinetics in relapsed patients. Blood 89: 3354-3360, 1997.

41. Park JW, Choi YJ, Jang MA, Baek SH, Lim JH, Passaniti T and Kwon TK: Arsenic trioxide induces $\mathrm{G} 2 / \mathrm{M}$ growth arrest and apoptosis after caspase-3 activation and bcl-2 phosphorylation in promonocytic U937 cells. Biochem Biophys Res Commun 286: 726-734, 2001

42. Gao F, Yi J, Yuan JQ, Shi GY and Tang XM: The cell cycle related apoptotic susceptibility to arsenic trioxide is associated with the level of reactive oxygen species. Cell Res 14: 81-85, 2004.

43. Hassani S, Ghaffari SH, Zaker F, Mirzaee R, Mardani H, Bashash D, Zekri A, Yousefi M, Zaghal A, Alimoghaddam K, et al: Azidothymidine hinders arsenic trioxide-induced apoptosis in acute promyelocytic leukemia cells by induction of p21 and attenuation of G2/M arrest. Ann Hematol 92: 1207-1220, 2013

44. Han YH, Kim SZ, Kim SH and Park WH: Arsenic trioxide inhibits the growth of Calu- 6 cells via inducing a $\mathrm{G} 2$ arrest of the cell cycle and apoptosis accompanied with the depletion of GSH. Cancer Lett 270: 40-55, 2008.

45. Kandasamy K and Srivastava RK: Role of the phosphatidylinositol 3'-kinase/PTEN/Akt kinase pathway in tumor necrosis factor-related apoptosis-inducing ligand-induced apoptosis in non-small cell lung cancer cells. Cancer Res 62: 4929-4937, 2002.

46. Chen X, Thakkar H, Tyan F, Gim S, Robinson H, Lee C, Pandey SK, Nwokorie C, Onwudiwe N and Srivastava RK: Constitutively active Akt is an important regulator of TRAIL sensitivity in prostate cancer. Oncogene 20: 6073-6083, 2001.

47. Chalhoub N and Baker SJ: PTEN and the PI3-kinase pathway in cancer. Annu Rev Pathol 4: 127-150, 2009.

48. Zhang X, Jia S, Yang S, Yang Y, Yang T and Yang Y: Arsenic trioxide induces $\mathrm{G} 2 / \mathrm{M}$ arrest in hepatocellular carcinoma cells by increasing the tumor suppressor PTEN expression. J Cell Biochem 113: 3528-3535, 2012.

49. Li Y, Qu X, Qu J, Zhang Y, Liu J, Teng Y, Hu X, Hou K and Liu Y: Arsenic trioxide induces apoptosis and G2/M phase arrest by inducing $\mathrm{Cbl}$ to inhibit PI3K/Akt signaling and thereby regulate p53 activation. Cancer Lett 284: 208-215, 2009.

50. Li YM and Broome JD: Arsenic targets tubulins to induce apoptosis in myeloid leukemia cells. Cancer Res 59: 776-780, 1999.

51. Liu Q, Hilsenbeck S and Gazitt Y: Arsenic trioxide-induced apoptosis in myeloma cells: p53-dependent G1 or G2/M cell cycle arrest, activation of caspase- 8 or caspase-9, and synergy with APO2/TRAIL. Blood 101: 4078-4087, 2003.

52. Wei N, Sun H, Wang F and Liu G: H1, a novel derivative of tetrandrine reverse P-glycoprotein-mediated multidrug resistance by inhibiting transport function and expression of P-glycoprotein. Cancer Chemother Pharmacol 67: 1017-1025, 2011.

53. Gibalová L, Sereš M, Rusnák A, Ditte P, Labudová M, Uhrík B, Pastorek J, Sedlák J, Breier A and Sulová Z: P-glycoprotein depresses cisplatin sensitivity in L1210 cells by inhibiting cisplatin-induced caspase-3 activation. Toxicol In Vitro 26: 435-444, 2012.

54. Pommier Y, Leteurtre F, Fesen MR, Fujimori A, Bertrand R, Solary E, Kohlhagen G and Kohn KW: Cellular determinants of sensitivity and resistance to DNA topoisomerase inhibitors. Cancer Invest 12: 530-542, 1994.

55. Burg D, Riepsaame J, Pont C, Mulder G and van de Water B: Peptide-bond modified glutathione conjugate analogs modulate GSTpi function in GSH-conjugation, drug sensitivity and JNK signaling. Biochem Pharmacol 71: 268-277, 2006.

56. Lee WK, Torchalski B, Kohistani N and Thévenod F: ABCB1 protects kidney proximal tubule cells against cadmium-induced apoptosis: Roles of cadmium and ceramide transport. Toxicol Sci 121: 343-356, 2011. 
57. Zhang X, Wu X, Li J, Sun Y, Gao P, Zhang C, Zhang H and Zhou G: MDR1 (multidrug resistence 1) can regulate GCS (glucosylceramide synthase) in breast cancer cells. J Surg Oncol 104: 466-471, 2011.

58. Duraj J, Zazrivcova K, Bodo J, Sulikova M and Sedlak J: Flavonoid quercetin, but not apigenin or luteolin, induced apoptosis in human myeloid leukemia cells and their resistant variants. Neoplasma 52: 273-279, 2005.

59. Kuo MT, Liu Z, Wei Y, Lin-Lee YC, Tatebe S, Mills GB and Unate H: Induction of human MDR1 gene expression by 2-acetylaminofluorene is mediated by effectors of the phosphoinositide 3-kinase pathway that activate NF-kappaB signaling. Oncogene 21: 1945-1954, 2002.
60. Zhou J, Liu M, Aneja R, Chandra R, Lage H and Joshi HC: Reversal of P-glycoprotein-mediated multidrug resistance in cancer cells by the c-Jun NH2-terminal kinase. Cancer Res 66: 445-452, 2006

61. Gu J, Tang Y, Liu Y, Guo H, Wang Y, Cai L, Li Y and Wang B: Murine double minute 2 siRNA and wild-type p53 gene therapy enhances sensitivity of the SKOV3/DDP ovarian cancer cell line to cisplatin chemotherapy in vitro and in vivo. Cancer Lett 343: 200-209, 2014.

62. Yang X and Pagé M: P-glycoprotein expression in ovarian cancer cell line following treatment with cisplatin. Oncol Res 7: 619-624, 1995 . 